\title{
Versatile Polymeric Cryogels and Their Biomedical Applications
}

\section{Çok Yönlü Polimerik Kriyojeller ve Biyomedikal Uygulamaları}

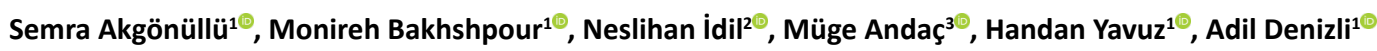 \\ ${ }^{1}$ Department of Chemistry, Hacettepe University, Ankara, Turkey. \\ ${ }^{2}$ Department of Biology, Hacettepe University, Ankara, Turkey. \\ ${ }^{3}$ Department of Environmental Engineering, Hacettepe University, Ankara, Turkey.
}

\section{ABSTRACT}

ryogels are interconnected macroporous materials, which are synthesized under semi-frozen conditions. They can

be either produced as pure polymeric or composite, that can find a variety of applications in several research field. The excellent features of composite cryogels such as, biocompatibility, physical resistance and sensitivity, making them extremely suitable for biomedical applications. They commonly take place in therapeutic, diagnostic and pharmaceutical applications in the field of biomedical research. This review focuses on the biomedical applications of composite cryogels, particularly in the field of tissue engineering, drug delivery systems and protein diagnosis.

\section{Key Words}

Cryogels, composite cryogels, biomedical applications.

\section{öz}

\footnotetext{
riyojeller, yarı donmuş koşullar altında sentezlenen birbirine bağlı makro gözenekli malzemelerdir. Birçok araştırma alanında çeşitli uygulamalar bulabilen kriyojeller saf polimerik veya kompozit olarak üretilebilirler. Biyouyumluluk, fiziksel direnç ve hassasiyet gibi kompozit kriyojelerin mükemmel özellikleri, onları biyomedikal uygulamalar için son derece uygun kılar. Genellikle biyomedikal araştırma alanındaki terapötik, teşhis ve farmasötik uygulamalarda yer alırlar. Bu derleme, özellikle doku mühendisliği, ilaç salınım sistemleri ve protein teşhisi alanındaki kompozit kriyojellerin biyomedikal uygulamalarına odaklanmaktadır.
}

\section{Anahtar Kelimeler}

Kriyojeller, kompozit kriyojeller, biyomedikal uygulamalar.

Article History: Oct 4, 2019; Revised: Nov 11, 2019; Accepted: Dec 12, 2019; Available Online: Apr 1, 2020.

DOI: https://doi.org/10.15671/hjbc.629355

Correspondence to: A. Denizili, Department of Chemistry, Hacettepe University, Ankara, Turkey.

E-Mail: denizli@hacettepe.edu.tr 


\section{INTRODUCTION}

$\mathrm{M}$ acroporous cryogels are hydrogel-based matrices that have interconnected macropores. They are formed in moderately frozen solutions of monomeric and polymeric precursors. The use of cryogels is of great importance in biomedical applications because of their biocompatibility, chemical and physical resistance and sensitivity.

There are several cryogel investigations in literature, especially in their structural characterization [1-3]. Cryogels have also found a wide range of applications in biomedical research, including regenerative medicine, tissue engineering, drug delivery systems (DDS) and protein recognition within cells, since they can swell and allow liquid exchange in their macroporous structure. Tissue engineering is the second most widely researched application field with more than $20 \%$ of total biomedical applications [4]. Particularly, biodegradable cryogels are widely used in tissue engineering as scaffolds for regenerating human tissues due to their structural similarity to the natural extracellular matrices (ECMs) in the body. Owing to their feasible application in DDS, the use of cryogels have gradually increased among the other type of materials. They have been extensively considered in sustained and controlled release devices for the delivery of water-soluble bioactive molecules as drugs with their high biocompatibility [5]. Moreover, recognition of biomacromolecules from their sources including blood, cells, and tissue, has become attractive for protein purification and separation methods. More recently, physical properties and the potential use of cryogels are reviewed comprehensively in biomedical applications [6].

In this extent, composite cryogels are introduced and recent applications are reviewed in the field of biomedical research, particularly in tissue engineering, drug delivery and protein recognition systems.

\section{Significance of Composite Cryogels in Biomedical Applications}

Cryogels play an important role in biomedical applications due to their biocompatibility, physical resistance and sensitivity (Figure 1). In some cases, the surface area of cryogels can be improved particularly in controlled release systems and separation processes. Therefore, particle embedding would be a useful improvement mode to use in the preparation of novel composite cryogels for increasing surface area [7]. This approach makes use of a combinatorial selection strategy to enhance adsorption and binding capacity. The advantage of the particle loaded cryogel adsorbents over packed bed systems and chemically functionalized cryogel adsorbents for protein applications are the combination of both high flow rate and high binding capacity. This originates from the fact that macroporous cryogels, when compared with chromatographic beads, have a very low flow resistance. The big pores in the cryogel

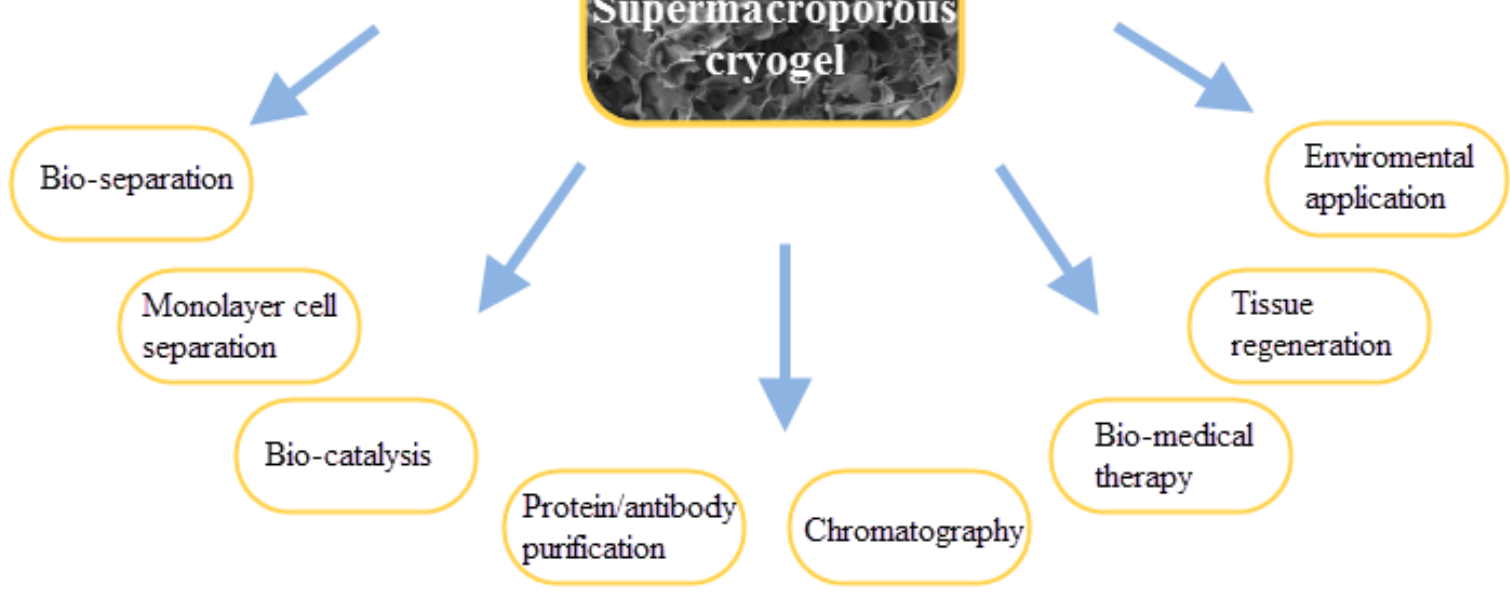

Figure 1. The application fields of supermacroporous cryogels. 
structure ensure convective transport of the target molecules to the active binding sites located on the surface of the embedded surface imprinted particles. Meanwhile, the use of small particles creates a high adsorption/ affinity area per unit of column volume due to the increased surface area. In addition, the embedding of surface imprinted particles in a macroporous matrix makes the column insensitive for possible particle deformation. In literature, in order to improve the functionality of adsorbents, nano-sized or micro-sized particles bearing different properties can be embedded or incorporated into monolith cryogel matrices to form composite cryogels [8]. These new cryogels are always produced by the mixing of micro particles with gel precursors followed by freezing the system at subzero temperatures $[9,10]$.

\section{Applications}

\subsection{Tissue Engineering}

The tissue engineering have gained considerable attention in practice, by the way, exploration and development of new and effective materials are the subjects of extensive research areas in recent scientific progress [11]. Cryogels have taken part in tissue engineering as a novel approach offering attractive prospects in several fields including biomedicine and biodegradable polymers $[12,13]$. These matrices could be identified as carriers for different kinds of molecules and cells. In addition, they have been efficient potentials as chromatographic supports for cell separations and cell culture [14]. In other words, cryogels have been existed as desirable polymeric gel structures due to their three-dimensional elastic sponge-like networks with their open porous structures and unique mechanical features [11]. Cryogels have the ability to mimic the three-dimensional structures of extracellular matrix (ECM) which is a major component of cells and network of some molecules including polymerized proteins such as collagen, laminin and elastin [15]. ECM has particular functionalities such as generating structural support, organizing the communications between cells, providing stability, in this respect, supervising cell proliferation and controlling cell differentiation.

In addition, ECM proteins have substantial, complex and key roles in conducting properly coordinated cellular activities via promoting signaling pathways and regulating matrix reconstitution [11].

In tissue engineering, scaffolds have been introduced as functional and attractive materials with the capability of behaving as artificial ECM. Scaffolds have met the require- ments with some advantages such as being biocompatible for enabling cell attachment and movement, biodegradable for facilitating cells to form their own ECM. Furthermore, desirable scaffolds should have strong mechanical character to perform presentable surgical operations and well-matched structure to fabricate effective implanted tissue-engineered constructs [16]. Moreover, large-porous constructions of scaffolds supply cellular nutrients and eliminate waste products from scaffolds. It is noteworthy to say that there have been widespread applications of scaffolds in the field of tissue/organ regeneration, therefore, regenerative medicine has recently begun to gain more interest over time [14].

In literature, it has been indicated that scaffolds have been used in airway, bladder, bone, skin, tendon, ligament, kidney, liver, intestine, pancreas, nerve, esophagus, valve, and heart muscle, cartilage regeneration [11]. Recent publications have reported different potential use of scaffolds as microbeads, cryogels, hydrogels, ceramics and nanofibers [14]. Among these, cryogels have long been considered as promising materials with their high potential in the regeneration of tissue [17]. Characterized hydrophilic property of cryogel enables to absorb a large amount of tissue fluids and accordingly, they have superior features over other polymeric materials due to their swelling property and elastic biocompatibility. In addition, gel matrix structure of cryogels with interconnected macropores enables cell penetration, contact and migration keeping both chemical and mechanical stability [14]. The preclinical and clinical attempts were made in the applications of cryogels as scaffolds in tissue engineering [18]. In other respects, cryogels have also some limitations along with their unique characteristics. They have a low surface area in comparison with other polymeric materials such as micro- and nanoparticles. For this reason, cryogels have low ligand binding capacity leading also low target adsorption capacity. Improvement of composite cryogels could deal with this major challenge. Composite cryogels can be synthesized by one-step polymerization either from monomer/ polymer solutions or particle suspensions under cryotropic conditions. Embedding particles inside cryogels offer an advance manner to enhance specific surface area and increase binding capacity of cryogels. Contribution of the porous matrix and selective capturing ability of the adsorbents embedded inside the matrix support to create individual combinations which are favorable for binding target molecules/cells [19]. 

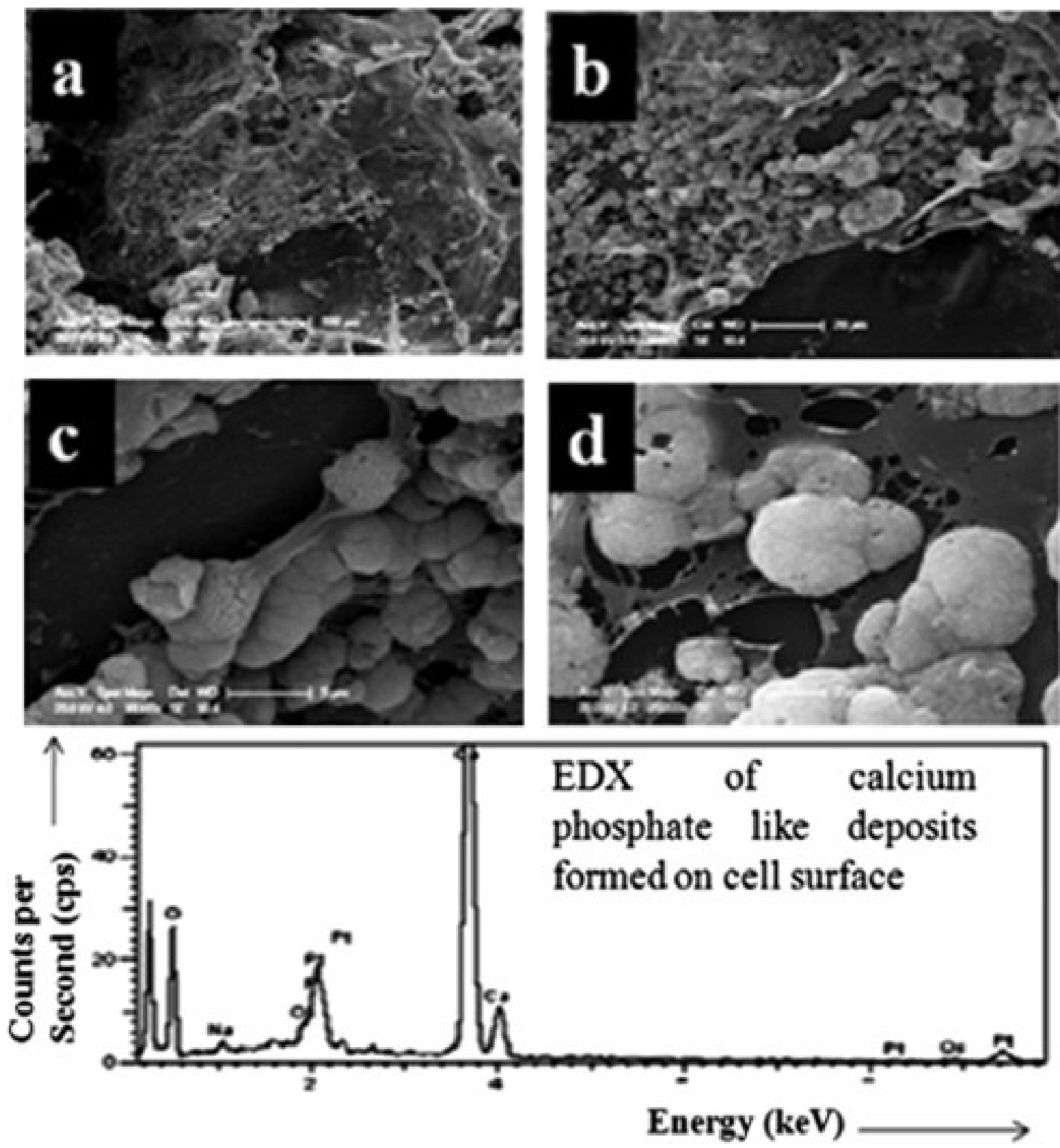

Figure 2. Scanning electron microscopic analysis at different magnifications (a-d) depicting large number of calcium-phosphate like deposits formed on the surface of PTAC bio-composite cryogels through osteoblastic activity after 24 days of culture.

Natural and/or synthetic polymers have been extensively examined to fabricate advanced scaffolds as medical devices. Naturally, derived polymers are of great importance in creating biomedical materials due to their safe biocompatibility. Chitosan, agarose, hyaluronic acid, gelatin, collagen, alginate, and silk could be given as examples for natural polymers. In addition, these polymers also regulate cellular interactions with minimal immune response and low toxicity. On the other side, among the typical adsorbents, synthetic polymers have been used to emerge desirable features and ob- tain manageable activity in tissue engineering. Polyglycolic acid, poly-vinylalcohol, poly-l-lactic acid, polycaprolactone, poly-orthoester have been preferred to apply as synthetic polymers [19]. Nevertheless, utilization of these polymers poses a challenge from the standpoint of injection and in the meantime bringing along serious infections. Besides natural and synthetic polymers, polymeric scaffolds and composites have been used for the preparation of cryogels which are planned to apply for tissue engineering [14]. In the rest of this section, recent approaches in the creation of composite 

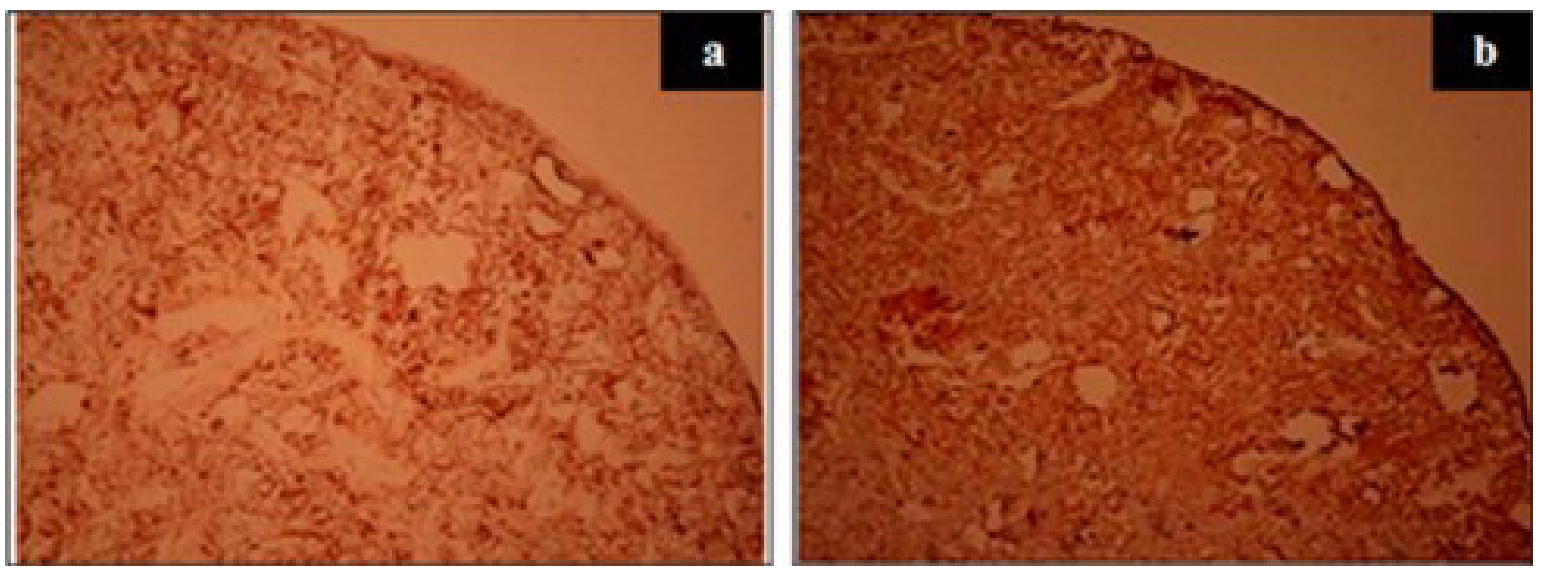

Figure 3. Alizarin red S staining of coated (a) and uncoated (b) PTAC bio-composite cryogels after 24 days of cell seeding (reproduced from (10) with permission).

cryogels and their applications in tissue engineering are concisely clarified.

\subsubsection{Applications}

Preparation of well-designed and relevant biomimetic adsorbents revealed from natural compositions of elastic (eg. skin), hard (eg. bone) and flexible connective (eg. cartilage) tissues have been still a challenge in the course of time. Composite cryogels have been applied for confronting alterations of cell actions and induction of molecule generation. In this respect, there have been several publications emphasizing biomedical applications of composite cryogels in tissue engineering [12].

Mishra et al. prepared a bio-composite cryogel by the incorporation of polyallylamine plasma on the polyvinylalcohol-tetraethyl orthosilicate-alginate-calcium oxide (PTAC). They examined the effect of plasma polymerization on physico-chemical and biological functionality to modify bone regeneration potential of human osteoblast cells. Figure 2 shows that high proliferation rate of calcium-phosphate like deposits was observed on the PTAC biocomposite cryogels with an osteoblastic property at the end of 24 days. Moreover, alizarin red S staining was performed for verification of the presence of calcium-phosphate like deposits in the polymeric structure. As it can be seen from Figure 3 , obvious color difference attracts the attention between coated and uncoated matrices. The obtained results showed that human osteoblasts show higher alkaline phosphatase formation and indicated delayed maturation/mineralization on plasma coated cryogels. It is considered that delayed mineralization of cells serves benefit in terms of seeding biomaterials with cells [20].
These results were further confirmed by electron dispersive X-ray spectroscopic analysis showing calcium phosphorus and oxygen peaks (reproduced from (10) with permission).

In another study, chitosan-agarose-gelatine (CAG) cryogels were synthesized with highly soft well porous and mechanical structure for cartilage tissue engineering applications. Chitosan and gelatin could maintain binding regions to cells with the advantage of their biocompatible properties. Agarose ensures elasticity to the gel matrices and stimulates the regeneration of soft cartilage tissue. These cryogels exhibited good cell growth and proliferation of primary goat chondrocytes. In vivo biocompatibility of them was verified with implantation analysis of the scaffolds. These results suggest the potential of CAG cryogels as a good three-dimensional scaffold for cartilage tissue engineering [18]. The other study of this research group was further aimed to reveal the ability of CAG cryogels in the production of neocartilage under in vitro conditions. In addition, in vivo experiments were performed with mice tissues and the potential usage of prepared cryogels were confirmed in the improvement of cartilage lesions [21].

Gupta et al. was used CAG cryogel scaffold once again to treat subchondral cartilage damages and bone defects in white rabbits. The treated cartilage was well regenerated and immunohistochemical experiments indicated that regenerated part of the cartilage tissue imitated native cartilage tissue without any immune rejection [22]. 
Mishra et al. was generated (PTAC) bio-composite cryogels for the repair of critical-sized cranial bone defects in Wistar rats. The obtained results were demonstrated the applicability of cryogels in bone regeneration and even osteoblastic differentiation [23].

In a study conducted by Salgado et al. collagen/nano hydroxyapatite cryogels were prepared to investigate in vitro biodegradation of human bone marrow stromal cells and differentiation of these cells into osteoblastic phenotype. Optimization experiments showed that composite cryogel having highest nanohydroxyapatite indicated highest mechanical resistance with enabling functional cell ingrowth. In vivo analysis performed with rats to examine subcutaneous and bone implantation. As a result of this study, it can be concluded that composite collagen/nano hydroxyapatite cryogels are promising materials for bone defects promoting enough osteo-conductivity [24].

Suner et al. synthesized a composite cryogel prepared by the combination of hyaluronic acid and halloysite nanotubes having mechanical strength and biocompatibility. Applications of these cryogels as scaffolds were carried out with various cells. Incorporation of halloysite nanotubes into hyaluronic acid resulted in a dramatic man cervical carcinoma cells and human colon cancer cells. The most remarkable point is that using a high concentration of halloysite nanotubes embedded into hyaluronic acid cryogels have given rise to an increase of mesenchymal stem cells growth [25].

In another study, a composite cryogel was prepared with incorporation of hydroxyapatite in the forms of bone-char, bio-glass, and nano-hydroxyapatite into chitosan-gelatin cryogels to determine their characteristics and also interpret their potentials on mineralization. Consequently, chitosan-gelatin cryogels including bone char showed biocompatibility, beneficent cell adherence and high mineralization. Bone char usage has been proven as a cost-effective and viable source for bone tissue repair and these features make these composite cryogels applicable in tissue engineering [26].

Raina et al. carried out research related to the improvement of osteo-induction using scaffolds with bone morphogenic protein-2. Silk fibroin, chitosan, agarose, and hydroxyapatite composite cryogels with/-out bioactive glass were fabricated to examine properties as carrier scaffolds. The reproduction of $\mathrm{C} 2 \mathrm{C} 12$ myoblasts and mesenchymal stem cells was achieved, but, it was shown that bioactive glass has no in vitro observable

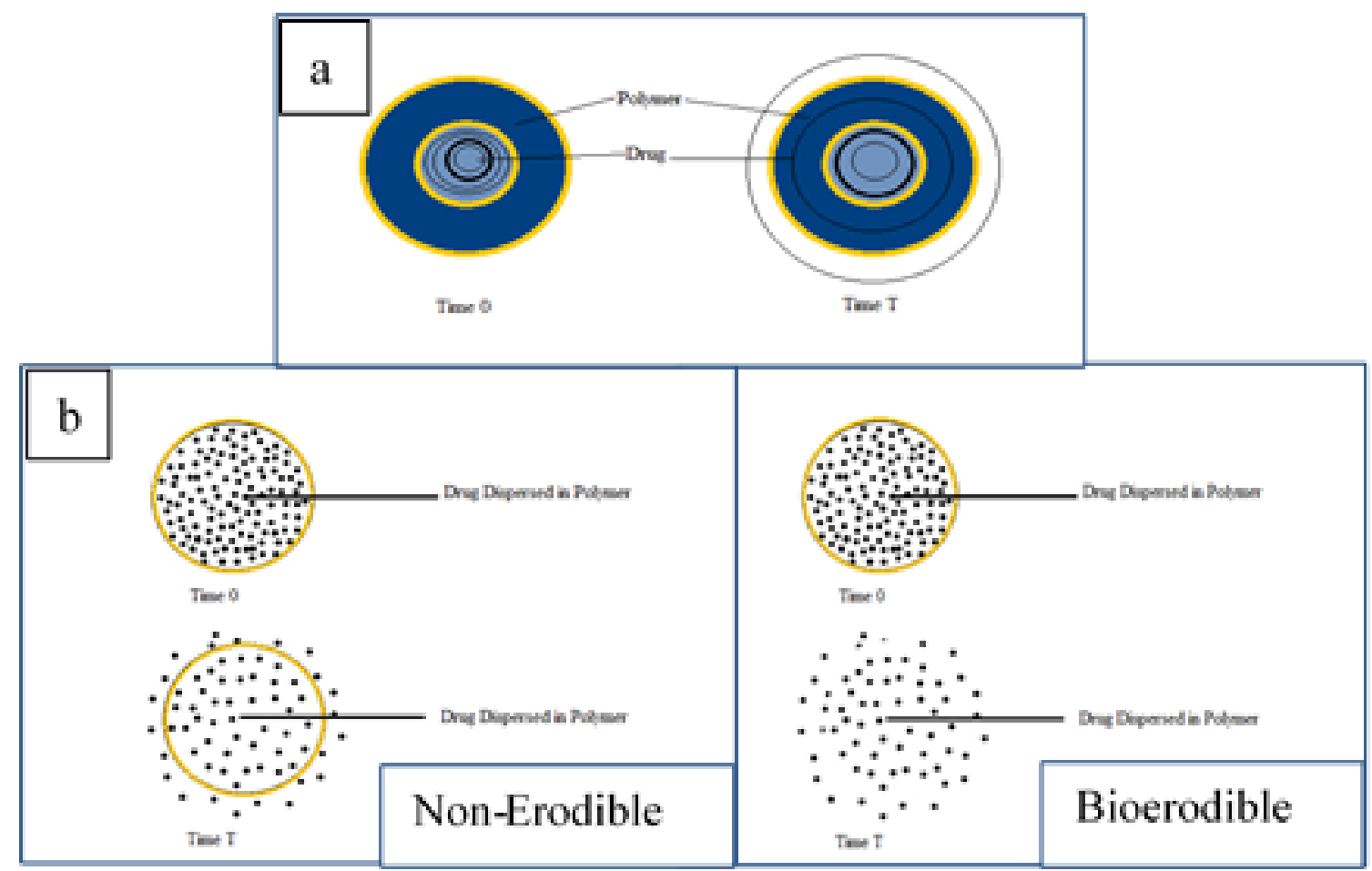

Figure 4. (a) Diffusion-controlled reservoir delivery system, (b) Diffusion-controlled matrix delivery system. 
nic protein-2 and zoledronic acid, ensuring good choices to bone grafts [27].

In a previous study, the ability of composite cryogel consisting of fibrinogen and gelatin on dermal regeneration was examined in the skin tissue. The movement of human dermal fibroblast through the scaffold was well found with increasing concentrations of fibrinogen of the scaffolds [28].

Takei et al. produced composite cryogels with doping some additives into cryogels to induce wound healing in skin. Chitosan-gluconic acid conjugate/poly(vinyl alcohol) composite cryogels doped with recombinant human basic fibroblast growth factor was evaluated in vivo for wound healing. The obtained results showed that these cryogels kept advantageous biological activities with speeding up the migration of inflammatory cells into the defective skin parts [29].

Temofeew et al. was studied on nucleus pulposus degeneration leads to back pain. The research team was produced a tissue-engineered scaffold for the regeneration of nucleus pulposus. For this purpose, a composite cryogel of gelatin and poloxamer 407 was built-up to develop water retention and results indicated dramatic increase in hydrophilicity and by the way cell infiltration. Newly designed composite cryogel offers a potential alternative to the high-priced spinal fusion surgery [30].

\subsection{Drug Delivery Systems}

To deliver the drugs in body, drug delivery (DD) systems are designed. Polymeric carriers are used in DD systems at specific sites and a certain time. DD systems attracted attention of scientists for applying these systems in the biomedical and pharmaceutical fields compound to achieve therapeutic effect. Controlled delivery of drugs improves their therapeutic effects while reducing the toxicity. DD systems have 4 types such as swelling-controlled, diffusion-controlled, stimulus-controlled, and erosion-controlled [31]. Diffusion-controlled delivery systems are two types as reservoir and matrix delivery systems (Figure 4).

A wide variety of polymeric biomaterials have been enhanced recently to delivery drugs to the human body. These classifications are micelles, polymeric capsules, cryogels, and liposomes. These have a core that con- tain the therapeutic drug with a polymer membrane outside (polymeric capsule). The drug release through the membrane by diffusion [32]. Water-insoluble drugs are successfully carried by micelles. Micelles are nanosized amphiphilic colloidal particles that have a hydrophobic core with a hydrophilic shell [33]. Liposomes with phospholipid bilayers are able to entrap water-soluble solutes in the aqueous inner core. Lipophilic drugs can be entrapped in the lipid bilayers [34]. Cryogels as a controllable and biocompatible materials can used in DD systems in the last few decades. Cryogels as stimuli-responsive materials have drawn a great attention of scientists. The sensitive response of cryogels to a chemical and physical changes make these material as a unique matrix for biomedical researches. Also, the smart structure of cryogels can caused that using as smart materials in the DD fields. Two strategies can be used for drug loading into cryogels; in-situ loading and post loading. In-situ drug loading formation can be used to apply cryogels for macromolecular drug delivery, tissue barriers, and tissue engineering. In the post loading formation, firstly cryogels are prepared and then absorption of drugs is achieved. Therapeutic drugs can be released by a stimulus causing a physical or chemical change in the DD systems, which is called stimulus-responsive DD systems [35].

Some environmental variables, such as elevated temperatures, and low $\mathrm{pH}$ are found in the body. For this reason, either temperature-sensitive, $\mathrm{pH}$-sensitive, temperature-sensitive, light-sensitive, electric signalsensitive and analyte-sensitive gels can be used for site specific controlled DD. Also, Stimuli-sensitive cryogels have enormous potential in various applications.

\subsection{1. $\mathrm{pH}$-sensitive}

A new type of stimuli-responsive in DDs are $\mathrm{pH}$-sensitive polymers. This method is mainly composed of amphiphilic block copolymers held together to form vesicles with a bilayer morphology. The $\mathrm{pH}$-sensitive cryogels are stable at $\mathrm{pH} 7.4$ but destabilize in the acidic environments such as endosomes. The drug can be released into the cytosol far from the transmembrane efflux pumps [36].

\subsubsection{Temperature-sensitive}

Thermosensitive polymers as an intelligent polymer have drawn a great attention in DD studies [37]. Nega- 
tively and positively thermosensitive are two classification of thermosensitive cryogels that negative have a lower critical solution temperature (LCST) and contract upon heating above the LCST. The polymer shrinks due to phase separation with increasing the temperature a certain value. The polymer chains expand and dissolve in water under this temperature. Cryogels show an on/ off drug release with off at high temperature and on at a low temperature in releasing of the drug. A positive effect of cryogels has an upper critical solution temperature (UCST), such cryogels contracts upon cooling below the UCST [38].

\subsubsection{Electric signal-sensitive}

The loading drug into cryogels sensitive to electric current can be the same, opposite charge or neutral to the polymer network. The releasing of a drug from electric signal-sensitive cryogels are dependent switched on and off of current at a specific site. The mechanism of the drug release is largely governed by the effects of the electric current on the cryogel matrix $[39,40]$.

\subsubsection{Analyte-sensitive}

Analyte-sensitive cryogels have been researched for many decades. The properties of cryogel networks can be used for many applications. Changes in cryogel properties are due to interactions between functional groups, the solvent, and ions. Additionally, analyte-sensitive cryogels uniquely interact with specific complex molecules, i.e., analytes. The development of analytesensitive cryogels needs to interaction with a specific molecule to cause an event, which can range from high-affinity binding to the degradation of the cryogels. Analyte-sensitive cryogels are listed in four classes. a) molecular imprinted recognitive, b) non-imprinted recognitive, c) biomolecule containing and d) enzymatically-response.

Molecular imprinting has gained great importance in sensor technology in the last decade. Molecularly imprinted polymers (MIPs) show high chemical, thermal and mechanical resistance. MIPs have structure stability and are capable of selectively recognize target molecules like conventional antibodies do [41]. Molecular imprinting technology (MIT) has received extensive attention in many biology and chemistry-related fields such as sensing, separation technologies, drug delivery, and catalysis. MIPs are designed to have recognition sites specific to the target molecule [42]. Size exclusion is the basic form in the non-imprinted recognition.
This method is obtained by the progressive addition of molecular barriers such as cross-links, tie points, and crystallites. The molecules below a specific molecular weight allow diffusing through the network of barriers, while larger molecular weight is excluded. Also, specific monomers can be used for non-covalent interactions with an analyte into matrix [43]. Bio recognition molecules can be conjugated in cryogels for generating synthetic approaches. Firstly, the molecules that are soluble and stable in the reaction medium, are acrylates and included during the polymerization. The molecules that denatured under rigid polymerization conditions are appropriate for this method [44]. Enzymes can be combined into cryogels with covalent linkage, encapsulation and interact peptide-substrate linkers. A therapeutic agent can be released by degradation of the enzyme such as linker. The advantages of enzymatically responsive systems are naturally biocompatible, highly specific and selective. Enzymatically responsive cryogels provide a great expectation for biomedical applications, and these unique biomaterials are predicted to have a significant impact on both research and clinical applications [45].

The gels can be used in other stimuli-responsive controlled release systems such as light-sensitive, ion-sensitive, and glucose-sensitive [46]. Glucose-sensitive controlled release gels are used for delivery of insulin because the delivery of insulin is more different than other drugs. Concanavalin A immobilized to introduce glucose has been used for insulin delivery [47].

\subsubsection{Application of cryogels in drug delivery systems}

Researchers are working on the design of effective and low cost cryogel-based drug delivery systems. Dinu et. al. prepared three-dimensional bio composites based on chitosan and clinoptilolite by cryogelation and investigated their potential application as drug carriers for diclofenac sodium and indomethacin. They reported the cumulative release of diclofenac sodium from the monoliths lower than $5 \%$ at $\mathrm{pH} 1.2$ and higher than $70 \%$ at $\mathrm{pH}$ 7.4. They also reported cumulative release of $6 \%$ indomethacin within the first hour in PBS from composite cryogels [48]. The group of Denizli [41, 49] prepared molecularly imprinted cryogels for the delivery of Mitomycin C (MMC). They synthesized MMC imprinted poly(hydroxyethyl methacrylate-N-methacryloyl-(L)histidine methyl ester)-Cu(II) (PHEMAH-Cu(II)) cyrogel membranes by free-radical bulk polymerization under 

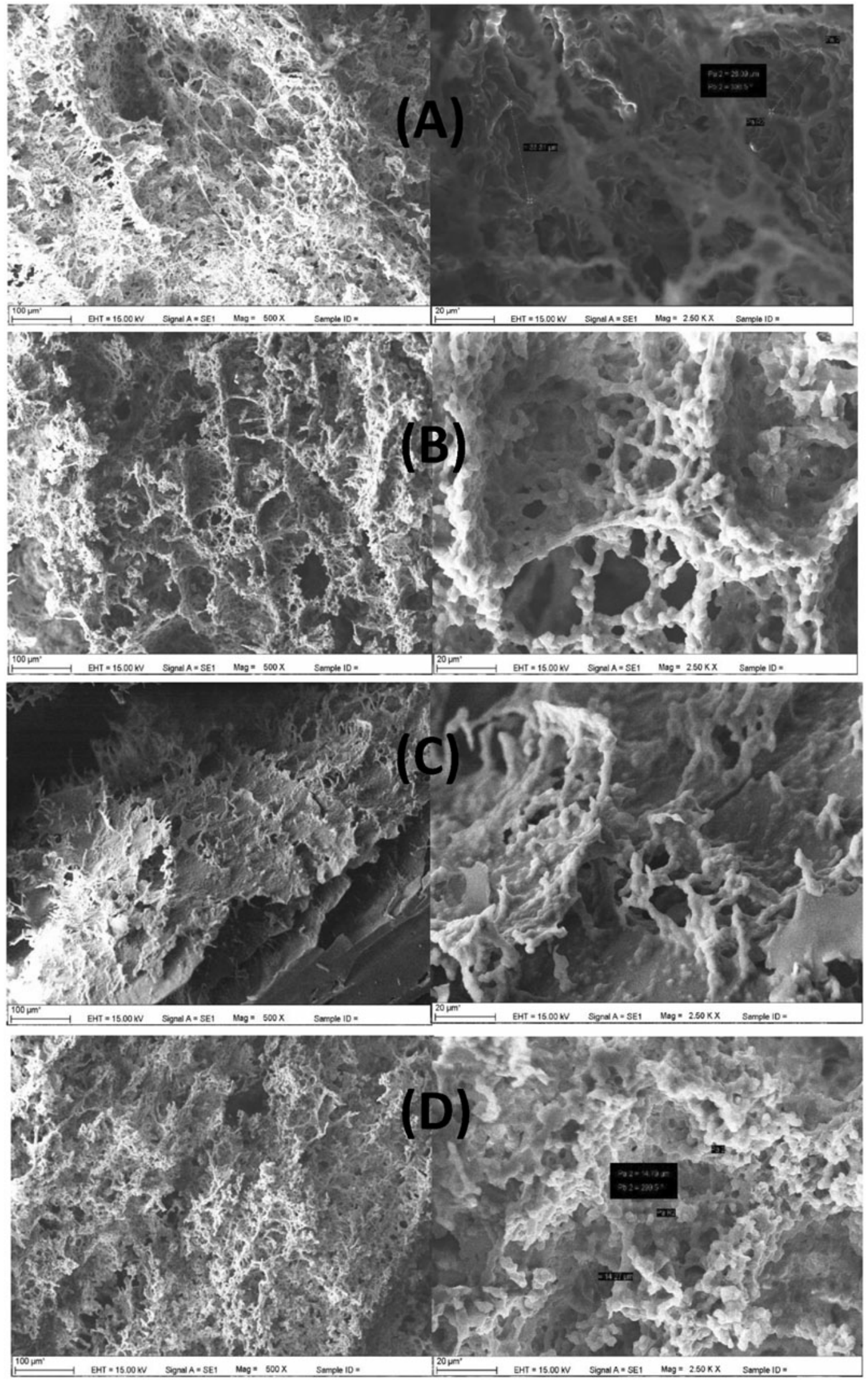

Figure 5. The SEM images of cryogel membranes synthesized at (A) $-14^{\circ} \mathrm{C},(\mathrm{B})-18^{\circ} \mathrm{C},(\mathrm{C})-20^{\circ} \mathrm{C}$ and (D) $-22^{\circ} \mathrm{C}$. 


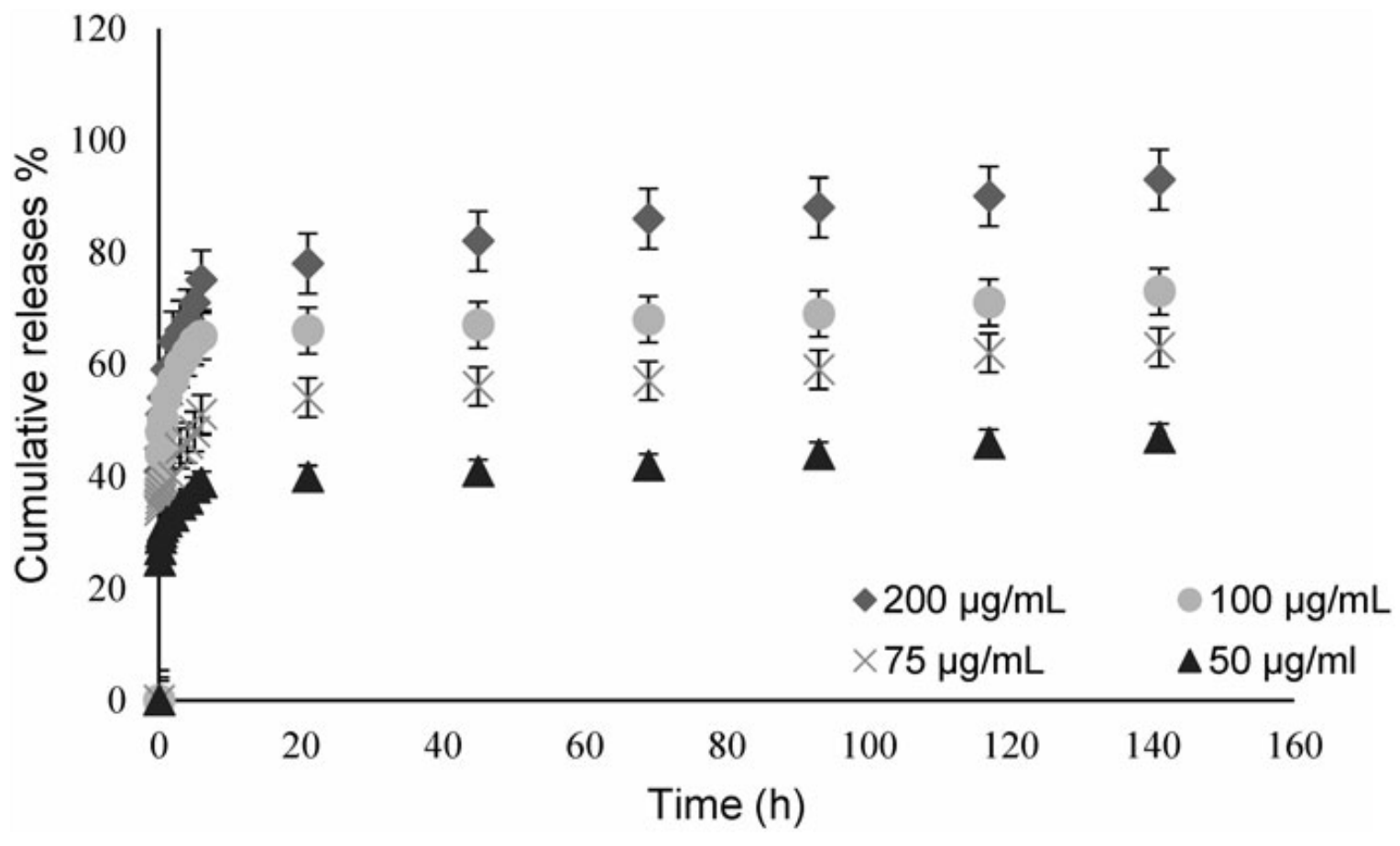

Figure 6. Effect of different amounts of template on the $\mathrm{MMC}$ release from cryogel membranes.

partially frozen conditions. They synthesized different molar ratio of HEMA:MBAAm at fixed amount of the template molecule for showing the effect of crosslinker in drug release rate. The increase of cross-linker ratio in the cryogel network can be caused more rigid and crosslinking structure of polymers. They synthesized different cryogels at $-14,-18,-20,-22^{\circ} \mathrm{C}$ polymerization temperatures. As seen in Figure 5 , the pore size of the cryogel membranes increased with increasing polymerization temperature. They studied the release rate of MMC with different amounts of template and showed an increasing cumulative release of $M M C$ with the increasing amount of drug (Figure 6).

Caka et. al. synthesized poly(2-hydroxyethyl methacrylate-methacryloylamidophenylalanine) membranes for the controlled release of curcumin via UVpolymerization technique. Curcumin is used as a folk remedy and a drug for some certain diseases and cancers. They reported 7.4 optimal $\mathrm{pH}$ and $37^{\circ} \mathrm{C}$ temperature for controlled release of curcumin. They obtained optimum values that very compatible with in-body usage without any extreme release factors [50]. Çetin and Denizli have prepared 5-fluorouracil (5-FU) imprinted cryogel discs using a coordination complex between metal-chelate monomer $\mathrm{N}$-methacryloyl-I-histidine (MAH) and 5-FU with the assistance of $\mathrm{Cu}(\mathrm{II})$ ion [5]. The complex was copolymerized with 2-hydroxyethyl methacrylate to produce PHEMAH-Cu(II) cryogel discs. Figure 7 shows the structure of 5-FU imprinted cryogel discs. It was observed that the cumulative release of 5-FU decreased by the increasing cross-linker density, and 5-FU transport mechanism was found to be non-Fickian.

In another study, Çetin et. al. prepared an implantable and degradable molecularly imprinted cryogel for $\mathrm{pH}$-responsive delivery of doxorubicin (DOX) [36]. The Release rate of DOX from cryogel discs increased in more acidic conditions. Kinetic studies have shown that the general release behavior of molecularly imprinted cryogel discs was a combination of diffusion and erosion control. Kostova et al. prepared temperature-sensitive poly(ethoxytriethyleneglycol acrylate) cryogels for controlled release of the hydrophilic drug verapamil hydrochloride. The controlled release of verapamil hydrochloride reported over a period of more than 8 $h$ [51].

\subsection{Protein Purification, Recognition and Depletion}

Biomolecules play significant roles in chemical, biological, food, and medical industries Proteins are of great industrial and scientific importance. Proteins are also important biomarkers for the diagnosis of diseases. There has been an unprecedented interest in molecular 

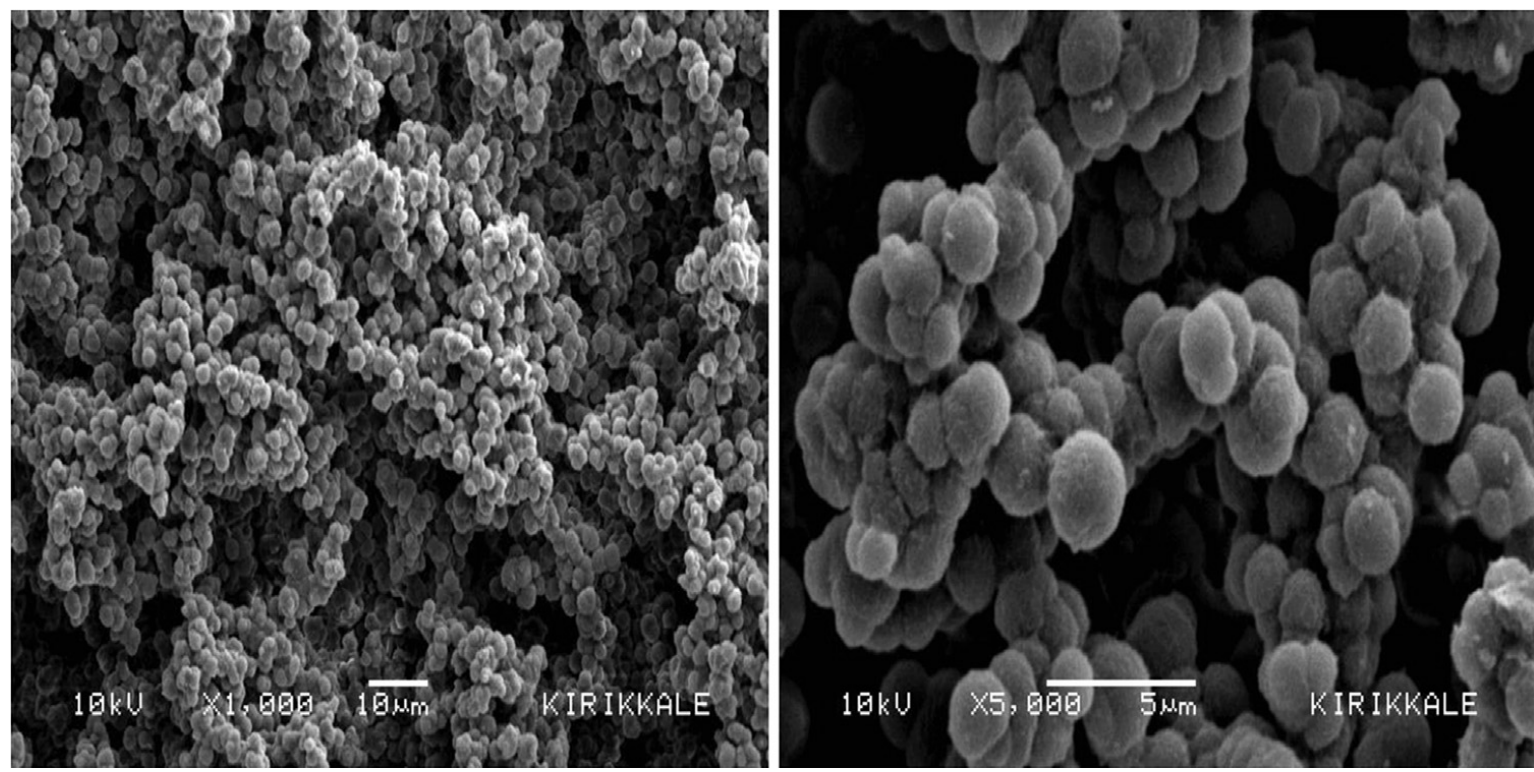

Figure 7. SEM images of 5-FU imprinted cryogel discs.

recognition and interaction involving proteins. By using synthetic methods, strong and perfect polymers that mimic antibody or enzyme-like selectivity and affinity have been designed $[52,53]$.

The favorable structural properties of cryogels such as adsorptive properties, short diffusion times, thinsurface films, tolerance to convective transport and low back-pressure are also used as promising adsorbent materials in various chromatographic methods including environmental, biotechnology, chromatography applications. The most favorable properties of cryogels in studies performed in these fields are that they can interact with whole blood without damaging the blood cells and do not require any sample pretreatment stage. The combination of the properties of cryogels applies in specific applications such as efficient chromatographic methods [52, 54, 55].

The purification of biomolecules is generally carried out with different affinity chromatography methods. Affinity chromatography is a most powerful technique, which reversible and biospecific interactions are used for the selective extraction, separation, purification and recognition of biologically active compounds from crude samples. The technique is also an indispensable tool for studying many biological processes, such as the mechanism of action of hormones, enzymes, cell-cell or protein-protein interactions and so forth. In this pro- cess, the target biomolecule is captured by the affinity ligand; the unbound molecules and solutes are removed by washing buffer and the target molecule of interest is finally eluted (Figure 8) [55].

Immunoglobulin $G$ (IgG), is the main serum immunoglobulin, and broadly utilized for treatment of diseases related to immunodeficiency in the clinic. For IgG purification, the most commonly utilized approaches are the high specificity protein $G$ or protein A based methods. Sun et al., designed a high adsorption capacity novel absorbent for the purification of IgG. They were prepared agarose beads embedded agarose-chitosan monolithic cryogels by cryo-copolymerization of agarose-chitosan blend solutions with glutaraldehyde as a cross-linker. The morphologies of agarose-chitosan monolithic cryogels were characterized by using scanning electron microscopy. The characterization results displayed that the synthesized cryogels possess interconnected pores of 10-100 $\mu \mathrm{m}$ size. The specific surface area of cryogels was calculated $350 \mathrm{~m}^{2} / \mathrm{g}$ and maximum adsorption capacity of IgG purification was found as $71.4 \mathrm{mg} \mathrm{lgG} / \mathrm{g}$. The composite cryogels displayed perfect stability, and can be reused at least 15 times [56].

IgG is important therapeutically molecule. IgG can be used as a substitute therapy in target cancer therapy and autoimmune, chronic inflammatory disorders, pri- 

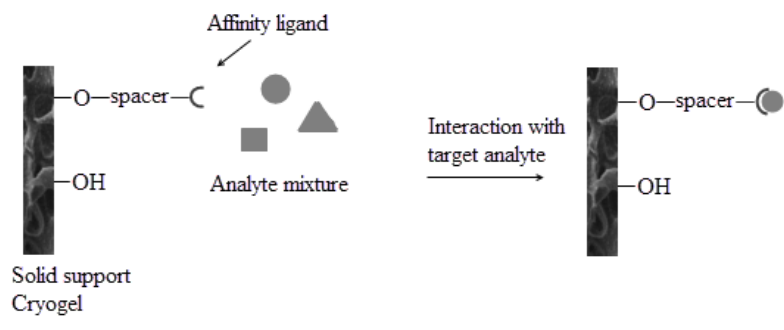

Figure 8. Schematic showing principle of affinity chromatography.

mary or secondary immunodeficiency, and idiopathic purpura. IgG has also been broadly used as an immunological tool in immunodiagnostic assays like antibody microarray, immunosensors, radioimmunoassay, and ELISA technologies. Therapeutic and immunodiagnostic assay needs highly pure IgG or complete purification of human IgG from human blood. Bakhshpour et al. prepared PHEMA based cryogels with immobilized metal affinity for purification of IgG. Poly(ethylene imine) (PEI) was used as the chelating ligand for covalently coupled with PHEMA cryogels. After, the $\mathrm{Cu}(\mathrm{II})$ ions were chelated to the PEl-attached PHEMA cryogels. The purification capacity was calculated $72.28 \mathrm{mg} / \mathrm{g}$ cryogel when PEI immobilized and Cu(II) loading were $87 \mathrm{mg} / \mathrm{g}$ and $246 \mathrm{mg} / \mathrm{g}$ polymer, respectively. As a conclusion, in this study they have reported novel synthesized cryogel column for selectively IgG purification [57]. Bakhshpour et al. synthesized two different composite cryogels for purification of IgG in another study. Thiophilic PHEMA based composite cryogel disks were synthesized with attachment of 2-mercaptoethanol as an affinity ligand. The maximum adsorption capacity was calculated 27.5 $\mathrm{mg} / \mathrm{g}$ and $68.7 \mathrm{mg} / \mathrm{g}$ for thiophilic PHEMA and thiophilic composite cryogel disks, respectively [58].

Monolithic columns are a type of cryogels and constitute a special adsorbent group for protein purification with many advantage such as kind of supermacropores, short residence time, short diffusion path, and low-pressure drop. Saylan et al. synthesized monolithic composite columns for purification of immunoglobulin G (IgG) by boronate affinity chromatography. Monolithic composite columns were polymerized in the presence of 4-vinyl phenyl boronic acid (VPBA) and 2-hydroxyethyl methacrylate. The performance of IgG separation of monolithic composite columns was determined with high performance liquid chromatography (HPLC). Adsorption experiments were carried out under chan-

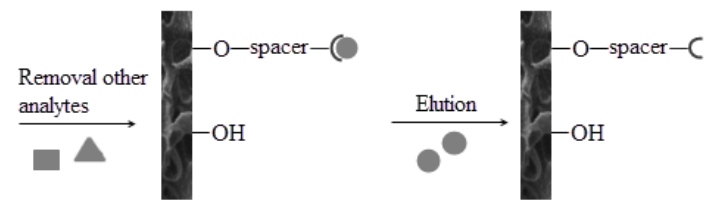

ging parameters such as $\mathrm{pH}$, IgG concentration, flow rate, ionic strength, and temperature. The maximum adsorption capacity was observed at $\mathrm{pH}$ 8.0. The selectivity experiments of the monolithic composite column were carried out with human serum albumin and hemoglobin as competitors. The IgG purification from human plasma was also performed [59].

Yang Chun et al. [60] prepared molecular imprinting amphoteric polyacrylamide cryogels for lysozyme, hemoglobin, ovalbumin, pepsin, and $\gamma$-globulin proteins. In polymerization solution was used acrylic acid and allylamine, acrylamide and N, N'-methylene bis-acrylamide as functional monomers. The acidic and basic functional groups were present in this polymer; it facilitates effective interactions with amphoteric proteins.

The proteins have greatly and broad scopes of molecular weights and isoelectric points. Regardless of the values of the isoelectric points and molecular weights, all target proteins showed higher retentions on the molecularly imprinted polymer than on the non-imprinted polymer. The highest and lowest imprinting capacity of MIP cryogel was showed. As a result of this study, it has been noted that amphoteric polyacrylamide cryogels are suitable for diverse target proteins and may be useful for protein purification, recognition, and depletion. In human serum proteins and small molecules successfully was isolated by Zhao et al [61]. In this study the multifunctional polymer cryogel, as a solid phase extraction (SPE) monolith easily prepared in a syringe. Cryogel monolith ( $\mathrm{pDC} / \mathrm{GO}-\mathrm{DE}$ ) was synthesized of diallyl dimethyl ammonium chloride (DC) and HEMA, that was modified with graphene oxide (GO) and N-diethylethanamine hydrobromide (DE). Different proteins isolated including lysozyme (Lys), bovine serum albumin (BSA), immunoglobulin $\mathrm{G}(\operatorname{IgG})$, transferrin, $\boldsymbol{\gamma}$-globulins, and their mixtures were studied as model analytes to evaluate the new 
material which was mainly dependent on ion-exchange and the hybrid hydrophobicity-hydrophilicity property of pDC/GO-DE cryogel. Additionally, the three-dimensional macroporous structure of cryogel contributed to size-selective isolation. More than $95 \%$ of the proteins were adsorbed within 10 minutes under physiological conditions in human serum diluted 10 times, and also the interference matrix in serum was effectively reduced. After recycling three times was still above $90 \%$ the extraction ratio of proteins in human serum [61].

In an effective manner, the research about protein imprinted polymers have increased drastically in recent years with the development of water-based polymer systems, namely hydrogels and cryogels. The macroporous structure of cryogels has allowed the use of these materials within different applications, particularly in affinity recognition and molecular imprinting methods. As reviewed in our previous studies; there are several studies focused on protein recognition and protein depletion by using cryogels, particularly composite cryogels both in affinity systems and molecular imprinting $[62,63]$.

Molecularly imprinted cryogels have also become attractive for researchers due to their high selectivity, specificity, efficient mass transfer and good reproducibility in the separation and purification of proteins [64].
In addition to these studies; the recent biomedical applications in affinity based and molecularly imprinted composite cryogels, in terms of protein depletion and purification, are focused in this section.

\subsubsection{Biomedical Applications}

\subsubsection{Protein Depletion}

Rheumatoid arthritis is a debilitating, progressive, chronic autoimmune disease that occurs in about $1 \%$ of adults. It is more common in people 40-70 years of age and about 2.5 times more women than men are affected. Alkan et al. [65], was designed poly(hydroxyethyl methacrylate) (PHEMA) supermacroporous cryogel for removal of IgM-antibody from human plasma. The PHEMA supermacroporous cryogel was prepared by cryopolymerization which continued in an aqueous solution of frozen monomer. Protein A immobilized PHEMA cryogels interacted with blood in the in-vitro system to determine blood-compatibility. The super-porous structure of PHEMA cryogel has been shown to make it possible to process blood cells without inhibiting the cryogel column (Figure 9). The maximum amount of IgM-antibody adsorption was $42.7 \mathrm{mg} / \mathrm{g}$. As a result, it was observed that PHEMA supermacroporous cryogel provided the reusability advantage and desorbed without loss of IgM-antibody adsorption capacity [65].

Bilirubin is an extremely hydrophobic molecule and transported in the bloodstream as a water-soluble
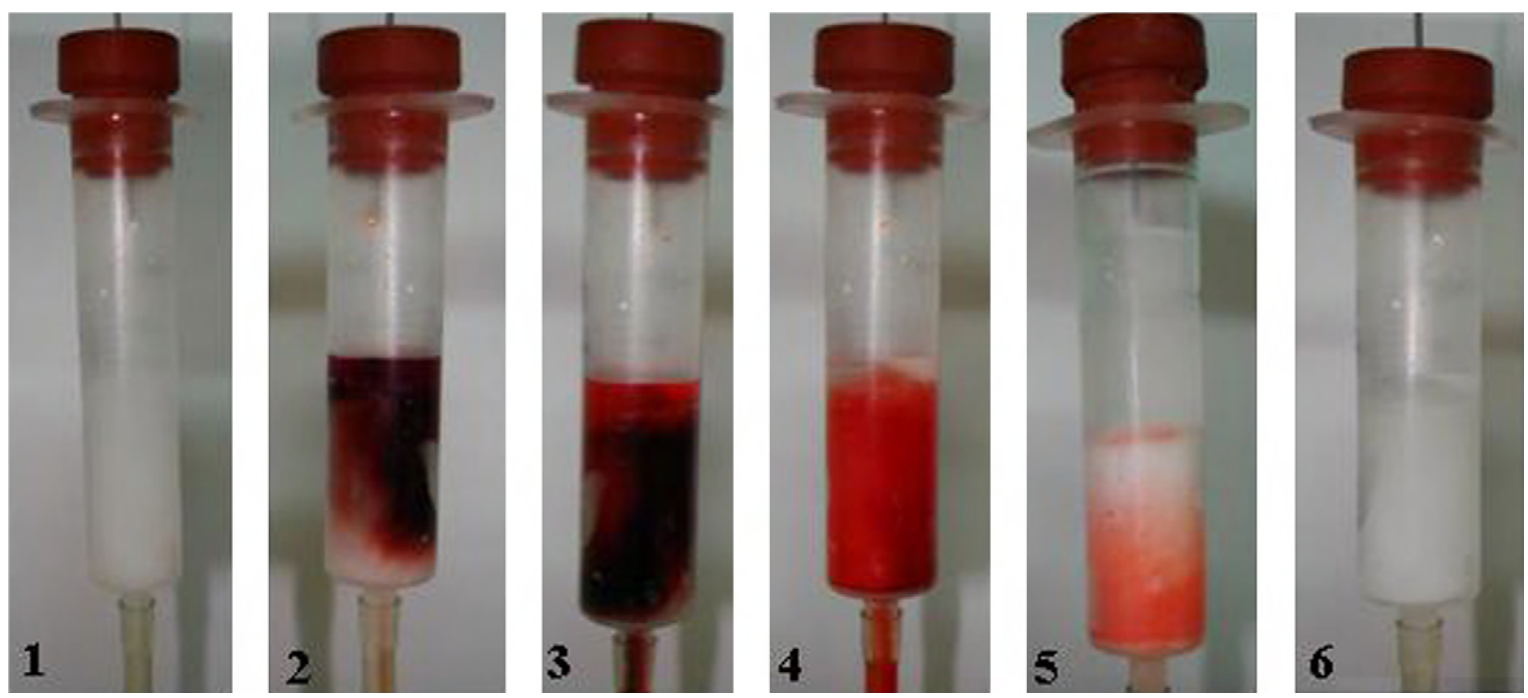

Figure 9. Flow behavior of whole blood through a PHEMA cryogel column. One-milliliter blood was applied to the cryogel column at a flow rate of $0.5 \mathrm{~mL} / \mathrm{min}$ in isotonic buffer solution. Column 1: column before application; columns 2-5: column during processing; column 6: column after the flow of blood sample. 
complex with albumin. It is conjugated to form bilirubin glucuronides in liver cells and excreted into the bile. Free bilirubin is extremely toxic because of its hydrophobicity. Disorders in bilirubin metabolism can lead to increased levels of free bilirubin and accumulate in phospholipid membranes and impair the performance of membranes. In addition, the presence of excess bilirubin in plasma may cause jaundice, hepatitis, brain damages or even death in newborn babies. Various methods have been made to extract bilirubin from hyperbilirubinemia human plasma for decreasing high bilirubin level to normal, such as hemoperfusion systems (removed toxic substances from patient's plasma with adsorbent substance) and plasma exchange. Perçin et al., prepared a novel N-methacryloyl-L-tryptophan methyl ester (MATrp) amino acid-based functional monomer containing poly-hydroxyethyl methacrylate (PHEMATrp) cryogel disc for removal of bilirubin from human plasma (Figure 10A). PHEMATrp cryogel disc was characterized by scanning electron microscopy (SEM), swelling tests, contact angle analysis elemental analysis, Brunauer-Emmett-Teller (BET) analysis, and surface energy calculations. In this study, bilirubin adsorption studies were performed in a batch system, and the maximum bilirubin adsorption capacity was found as $22.2 \mathrm{mg} / \mathrm{g}$ cryogel disc (Figure 10B). It was concluded that PHEMATrp cryogel discs provide economic advantages to their performance in reusability [66].

Cytapheresis is a commonly used extracorporeal separation technique aimed the elimination of certain types of blood cells from the circulating blood. Recently, cytapheresis has been shown to be clinically effective in a variety of illness cases, including autoimmune di- sorders, rheumatoid arthritis, leukemia, and sickle-cell anemia and renal allograft rejection. There are three major extracorporeal leukocyte removal therapies in the clinical area, including the centrifugation method, filtration, and the adsorptive method using beads or fibers. Akende et al., were produced an affinity-based macroporous monolithic cryogel with a structure of interconnected pores. The PHEMA cryogel affinity column was synthesized by free radical polymerization at $-12^{\circ} \mathrm{C}$. The PHEMA cryogel was functionalized with biological ligands. Haemolytic potential of PHEMA cryogel was settled by measuring free haemoglobin after blood filtration through the column. Anti-human albumin antibody was chemically combined with epoxy-derived monolithic cryogels and then the binding activity of anti-human albumin to cryogel was determined. It is shown that about $100 \%$ of the red blood cells pass through the column without evidence of hemolysis in blood. It has been reported that $\sim 82 \%$ of human serum albumin is kept on the monolithic IgG anti-human albumin cryogel matrix. The results have shown that PHEMA monolithic cryogel is a non-hemolytic material that can be functionalized with the antibody and therefore may be a matrix suitable for use in the extracorporeal apheresis system (Figure 11) [67].

\subsubsection{Protein Imprinting}

Molecularly imprinted polymers (MIPs) are synthetic materials designed to selectively recognize target molecules. MIPs are synthesized to reach specific interactions between a target analyte and polymeric matrices. This highly stable polymeric structure has perfect functions and properties by carrying specific predetermined binding sites to specific target analytes [68]. MIPs have
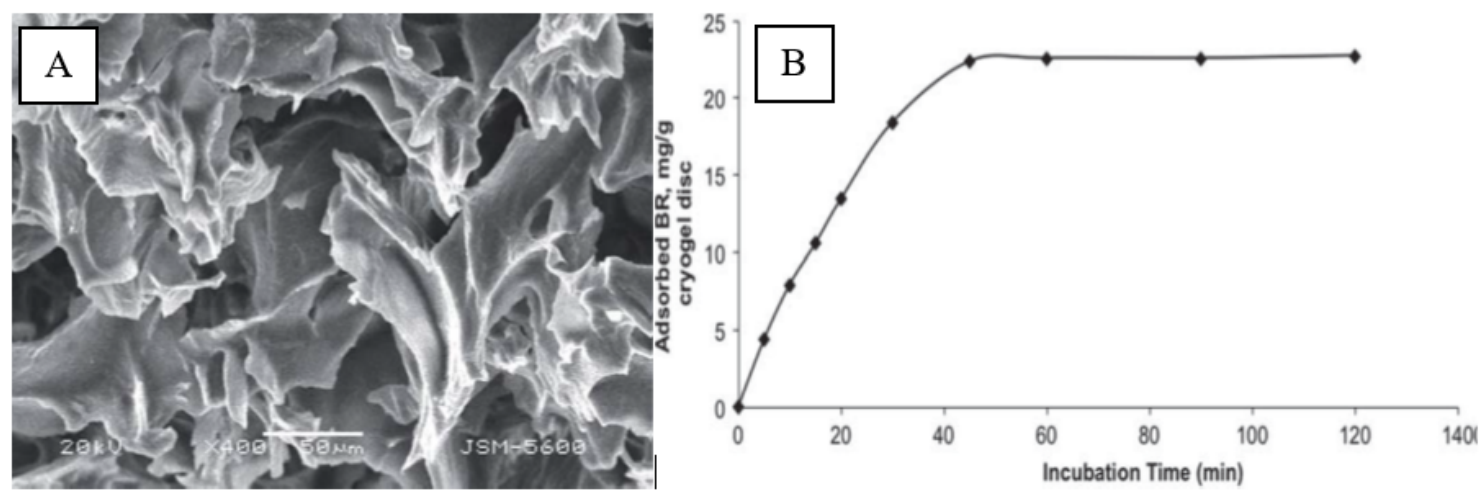

Figure 10. (A) SEM image of PHEMATrp cryogel disc; (B) The time dependence of the adsorption values of bilirubin on PHEMATrp cryogel disc. Bilirubin concentration: $1.0 \mathrm{mg} / \mathrm{mL}$; $\mathrm{mdry}: 0.034 \mathrm{~g} ; \mathrm{V}: 10 \mathrm{~mL} ; \mathrm{T}: 25^{\circ} \mathrm{C} ; \mathrm{t}: 2 \mathrm{~h}$. 

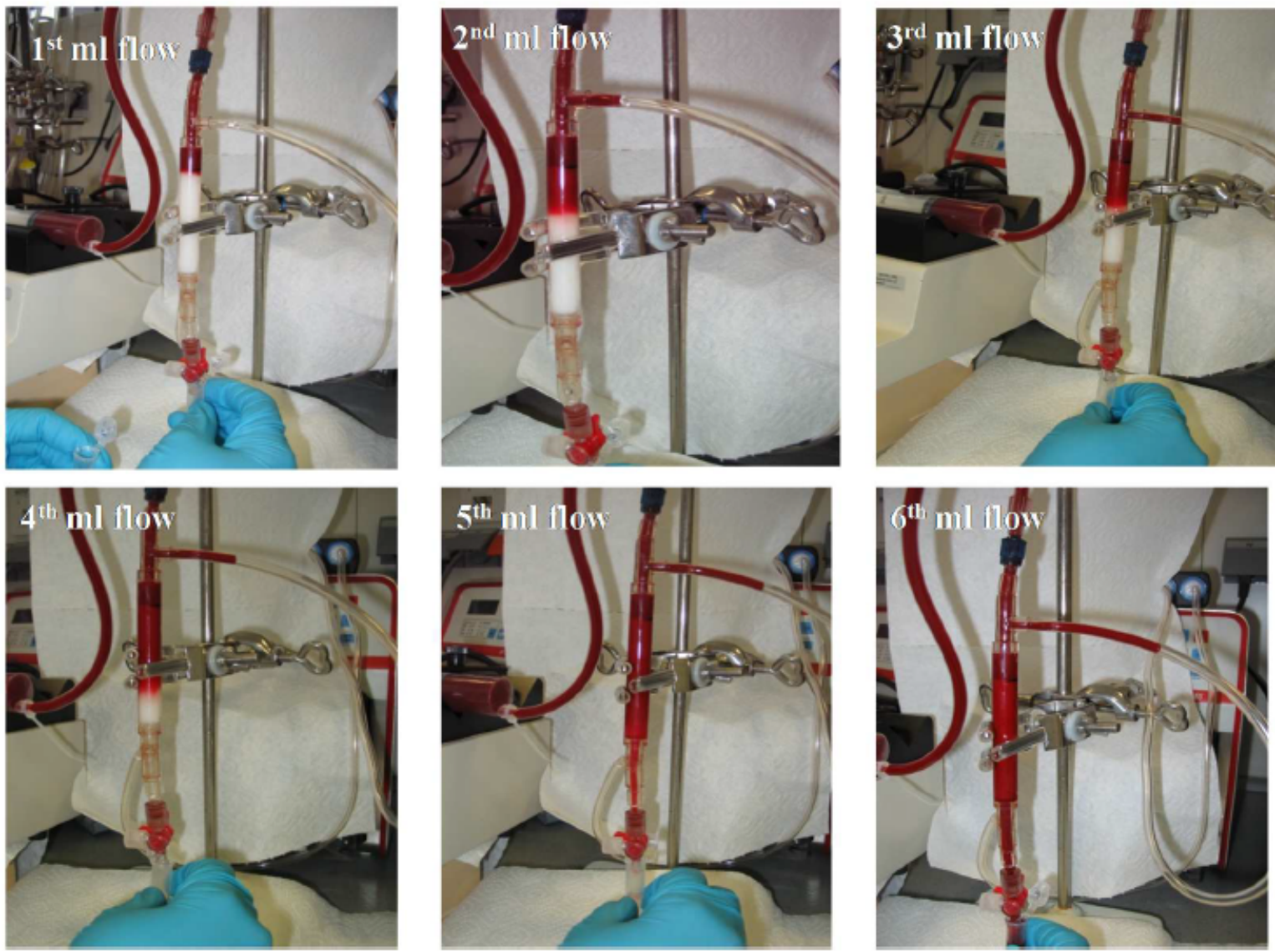

Figure 11. Flow of blood passing through the cryogel matrix at different times. No side flow leakage within the column was observed

unique properties such as high specificity, ease of mass preparation, thermal and chemical stability, low cost and ease of reusability [69]. Recently, MIPs has been involved in applications especially in protein related fields fields; such as molecular recognition, purification, separation, catalysis, disease diagnose and therapy [68]. Protein-imprinted polymers have evoked widespread interest to mimic molecular recognition systems in nature, including enzymes, antibodies, cells, and viruses. Technical and scientific development in the area leads to attractive applications in biomarker discovery, illness diagnosis, proteomics, and environmental analysis. Molecularly imprinted polymers (MIPs) are perfect tools to work the interactions between polymeric matrices and template and a polymeric matrix [70].

The first and important task with complex samples in proteomics and biomarker discovery is generally to deplete abundant proteins. For this, protein depletion was performed by various methods including metal affinity, immunoaffinity, combinatorial peptide ligand library, multidimensional chromatography, and others [71].
The adsorption performances of cryogels for various proteins are summarized in Table 1. Yang et al. synthesized supermacroporous cryogel to deplete abundant proteins. Molecularly imprinted and non-imprinted cryogels were prepared in the presence acrylamide, $\mathrm{N}, \mathrm{N}$-methylene bisacrylamide and sodium hydrogen sulfite. This study was made by different polymers by adding different amounts of human serum. Cryogenic polymerization was carried out at $-20^{\circ} \mathrm{C}$ for $24 \mathrm{~h}$. Chromatography and electrophoresis studies showed that albumin, serotransferrin, and globulins as most abundant proteins were depleted by molecularly imprinted cryogel columns. After depletion, the low abundance proteins identified by SDS PAGE, peptide fingerprint analysis, and MALDI TOF-MS were uncovered [71].

Interferons are cytokines, produced by virally infected cells, are very significant biological proteins. These proteins exhibit cytotoxic, immunomodulatory, antiviral, antitumor and antiproliferative activities also enhance the expression of the major histocompatibility antigens. There are three different major types of interferon which 
separate structural, biochemical and antigenic properties. These are alpha interferon ( $\alpha$-IFN), beta interferon $(\beta$-IFN), and gamma interferon ( $\gamma$-IFN). The $\alpha$-IFN is mainly produced by monocytes and B-lymphocytes. a-IFN is generally used in the treatment of chronic hepatitis $B$, hepatitis $C$, hairy cell leukemia, and diverse types of cancer. Purification of interferons is important for the treatment of many diseases including cancers, tumors and hepatitis. Çorman et al. alternatively synthesized molecular imprinting-based cartridges for the purification of interferons from aqueous solutions. This alternative approach provided high selectivity for the target molecule and was shown to provide a rapid separation. Cryogel cartridges were prepared with molecular imprinting technique in the presence of recombinant interferon $\alpha-2 b$. The specific filtration cartridges were characterized by scanning electron microscopy, Fourier-transform infrared spectrophotometry, and swelling tests. The adsorption studies different amounts of recombinant interferon $\alpha-2 b$ were performed at different $\mathrm{pH}$ values, centrifugation speeds, temperatures, and ionic strengths. The selectivity studies were carried out by using insulin, immunoglobulin G (IgG) and human serum albumin (HSA), lysozyme, myoglobin and carbonic anhydrase in competitive or uncompetitive conditions. Interferon purification by this alternative technique was obtained effectively and highly selective [72].

Proteins can be important biomarkers for the diagnosis of diseases. Hemoglobin ( $\mathrm{Hb}$ ), a major protein of red blood cells, is constitutes $95 \%$ of the total cytosolic proteins. In proteomic studies, a high abundance of $\mathrm{Hb}$ makes it hard to detect low abundance proteins, which are potential biomarkers. For this reason, $\mathrm{Hb}$ depletion from red blood cell hemolysate is very significant.

Baydemir et al. prepared molecularly imprinted based composite cryogel for depletion of hemoglobin from human blood. In the presented study, they describe a method that used molecularly imprinted microparticles embedded into cryogel to form composite cryogels. The molecularly imprinted microparticles were prepared in the presence of amino acid-based monomer $\mathrm{N}$-methacryloyl-L-histidine (MAH) as metal coordinating functional monomer. Hemoglobin imprinted poly(hydroxyethyl methacrylate-N-methacryloylL-histidine) (PHEMAH-Ni(II)-Hb) microparticles were synthesized (size range of 20-71 $\mu \mathrm{m}$ ). For this purpose they synthesized poly(hydroxyethyl methacrylate) based cryogel with high gel fraction yields up to $90 \%$, and characterized by scanning electron microscopy, Fourier transforms infrared spectrophotometer, flow dynamics swelling studies, and surface area analysis. Molecularly imprinted composite cryogel have a high binding capacity and selectivity for hemoglobin in the presence of albumin, myoglobin, and immunoglobulin G. In this study molecularly imprinted composite cryogel column was successfully performed in fast protein liquid chromatography system for selective depletion of hemoglobin for human blood. The depletion ratio was highly increased by embedding microspheres into the cryogel (93.2\%). As a result, molecularly imprinted composite cryogel can be reused many times without a significant reduction in hemoglobin adsorption capacity [73].

\section{Concluding Remarks}

Macroporous cryogels are hydrogel adsorbents that have interconnected macropores and are created in moderately frozen solutions of monomeric precursors $[77,78]$. Cryogels has various applications in the biotechnological, biomedical, and pharmaceutical fields. Also, cryogels are utilized in various medical applications such as tissue engineering, drug delivery systems (DDS) and protein recognition systems.

By this manner, composite cryogels are utilized as scaffolds for new tissues because of their structural similarity to the natural extracellular matrices in the body. In water cryogels are insoluble and swell when immersed. These polymeric carriers due to their high biocompatibility have also been broadly considered in controlled and sustained release devices for delivery of water-soluble drugs. DDS began to extend from small pharmaceutical drugs to macro biomolecules, such as proteins with the fast development of material, which macro-scale evolved into micro- and nano-scale. Thus, cryogels are new alternatives as drug delivery matrixes. In addition to; selective and efficient purification and depletion of proteins from crude samples, gained much interest in affinity recognition and molecular imprinting based composite cryogels by embedding nano and micro particles into cryogel structure to enhance the surface area and their binding capacity. 
Table 1. The adsorption performances of cryogels for various proteins.

\begin{tabular}{|c|c|c|c|c|c|c|}
\hline $\begin{array}{l}\text { Cryogel } \\
\text { materials }\end{array}$ & Target & Sample & $\begin{array}{c}\text { Cryogels } \\
\text { preparation } \\
\text { time/ } \\
\text { temperature }\end{array}$ & Initiator & $\begin{array}{l}\text { Adsorption } \\
\text { capacity }\end{array}$ & Author \\
\hline \multicolumn{7}{|l|}{ Purification } \\
\hline PHEMA/PEI & $\lg G$ & Human plasma & $-12^{\circ} \mathrm{C}$ for $24 \mathrm{~h}$ & APS/TEMED & $72.28 \mathrm{mg} / \mathrm{g}$ & $\begin{array}{l}\text { Bakhshpour, } \\
2016 \text { [57] }\end{array}$ \\
\hline $\begin{array}{l}\text { Thiophilic } \\
\text { P(HEMA- } \\
\text { EGDMA) beads } \\
\text { embedded } \\
\text { PHEMA }\end{array}$ & $\lg G$ & Human plasma & $-12^{\circ} \mathrm{C}$ for $24 \mathrm{~h}$ & APS/TEMED & 68.7 mg/g & $\begin{array}{c}\text { Bakhshpour, } \\
2014 \text { [58] }\end{array}$ \\
\hline $\begin{array}{l}\text { Agarose beads } \\
\text { embedded- } \\
\text { chitosan }\end{array}$ & $\lg G$ & Human plasma & $\begin{array}{c}+5 \text { to }-20^{\circ} \mathrm{C} \text { for } \\
18 \mathrm{~h}\end{array}$ & Temperature & 71.4 mg/g & Sun, 2012 [56] \\
\hline $\begin{array}{l}\text { poly(HEMA- } \\
\text { VPBA) }\end{array}$ & $\lg G$ & Human plasma & $-12^{\circ} \mathrm{C}$ for $24 \mathrm{~h}$ & APS/TEMED & $0.13 \mathrm{mg} / \mathrm{g}$ & Saylan 2014 [59] \\
\hline $\mathrm{pDC} / \mathrm{GO}-\mathrm{DE}$ & $\begin{array}{l}\text { Lys, BSA, IgG, } \\
\text { transferrin, } \\
\text { ү-globulins }\end{array}$ & Human plasma & $-20^{\circ} \mathrm{C}$ & & & Zhao 2019 [61] \\
\hline $\begin{array}{c}\text { Composite/ } \\
\text { PHEMA/MAPA }\end{array}$ & Lysozyme & $\begin{array}{c}\text { Chicken egg } \\
\text { white }\end{array}$ & $-16^{\circ} \mathrm{C}$ for $24 \mathrm{~h}$ & APS/TEMED & $57.3 \mathrm{mg} / \mathrm{g}$ & $\begin{array}{c}\text { Baydemir, } 2015 \\
\text { [74] }\end{array}$ \\
\hline \multicolumn{7}{|l|}{ Imprinting } \\
\hline $\begin{array}{l}\text { acrylamide, } \\
\text { MBAAm }\end{array}$ & $\begin{array}{l}\text { Albumin, } \\
\text { serotransferrin, } \\
\text { globulins }\end{array}$ & & $-20^{\circ} \mathrm{C}$ for $24 \mathrm{~h}$ & APS & 26 mg/g & Yang, 2017 [71] \\
\hline PHEMA-MATrp & Interferon $\alpha-2 b$ & $\begin{array}{l}\text { Multi-protein } \\
\text { solutions }\end{array}$ & $-12^{\circ} \mathrm{C}$ for $24 \mathrm{~h}$ & APS/TEMED & $17.9 \mu \mathrm{g} / \mathrm{g}$ & $\begin{array}{c}\text { Çorman, } 2015 \\
\text { [72] }\end{array}$ \\
\hline $\begin{array}{l}\text { PHEMA-MAH- } \\
\text { Ni(II) }\end{array}$ & Hemoglobin & Human blood & $-18^{\circ} \mathrm{C}$ for $24 \mathrm{~h}$ & APS/TEMED & 23.4 mg/g & $\begin{array}{c}\text { Baydemir, } 2014 \\
\text { [73] }\end{array}$ \\
\hline $\begin{array}{l}\text { Acrylamide- } \\
\text { BisAM-allyl } \\
\text { amine }\end{array}$ & $\begin{array}{l}\text { Lysozyme, } \\
\text { pepsin, } \\
\text { ovalbumin, } \\
\text { hemoglobin, } \\
\text { and } \text {-globulin }\end{array}$ & PBS buffer & $-20^{\circ} \mathrm{C}$ for $24 \mathrm{~h}$ & APS & & Yang 2016 [70] \\
\hline $\begin{array}{l}\text { Composite/ } \\
\text { PHEMA }\end{array}$ & Albumin & Human serum & $-12^{\circ} \mathrm{C}$ for $16 \mathrm{~h}$ & APS/TEMED & $98.2 \mathrm{mg} / \mathrm{g}$ & $\begin{array}{c}\text { Andaç, } 2012 \\
{[75]}\end{array}$ \\
\hline \multicolumn{7}{|l|}{ Depletion } \\
\hline $\begin{array}{l}\text { PHEMA/ } \\
\text { MBAAm }\end{array}$ & IgM-antibody & Blood & $-16^{\circ} \mathrm{C}$ for $24 \mathrm{~h}$ & APS/TEMED & 42.7 mg/g & Alkan, 2010 [65] \\
\hline PHEMA/MATrp & Bilirubin & Human plasma & $-16^{\circ} \mathrm{C}$ for $24 \mathrm{~h}$ & APS/TEMED & $22.2 \mathrm{mg} / \mathrm{g}$ & $\begin{array}{c}\text { Perçin, } 2012 \\
\text { [66] }\end{array}$ \\
\hline $\begin{array}{l}\text { HEMA and AGE, } \\
\text { MBAAm }\end{array}$ & $\begin{array}{c}\text { Hemoglobin/ } \\
\text { HSA }\end{array}$ & Red blood cells & $-12^{\circ} \mathrm{C}$ for $18 \mathrm{~h}$ & APS/TEMED & & $\begin{array}{c}\text { Akande, } 2015 \\
\text { [67] }\end{array}$ \\
\hline $\begin{array}{c}\text { PHEMA/PEGDA- } \\
\text { MAPA }\end{array}$ & Albumin & Human plasma & $-12^{\circ} \mathrm{C}$ for $16 \mathrm{~h}$ & APS/TEMED & $31.0 \mathrm{mg} / \mathrm{g}$ & $\begin{array}{c}\text { Andaç, } 2013 . \\
\text { [76] }\end{array}$ \\
\hline
\end{tabular}




\section{References}

1. S. Hajizadeh, H. Kirsebom B. Mattiasson, Characterization of macroporous carbon-cryostructured particle gel, an adsorbent for small organic molecules, Soft. Matter., 6 (2010) 5562-5569.

2. P. Persson, O. Baybak, F. Plieva, I.Y. Galaev, B. Mattiasson, B. Nilsson, A. Axelsson, Characterization of a continuous supermacroporous monolithic matrix for chromatographic separation of large bioparticles, Biotechnol. Bioeng. 88 (2004) 224-236.

3. S. Akgönüllü, H. Yavuz, A. Denizli, Preparation of imprinted cryogel cartridge for chiral separation of I-phenylalanine, Artif. Cell Nanomed. B., 45(4) (2017) 800-807.

4. D.B; Raina, A. Kumar, Cryogels and related research: a glance over the past few decades in super macroporous cryogels, ed A. Kumar, CRC Press, (2016) 3-34.

5. K. Cetin, A. Denizli 5-Fluorouracil delivery from metal-ion mediated molecularly imprinted cryogel discs, Colloid. Surface. B., 126 (2015) 401-406

6. T.M.A. Henderson, K. Ladewig, D.N. Haylock, K.M. McLean, A.J. O'Connor, Cryogels for biomedical applications, J. Mater. Chem. B., 1 (2013) 2682-2695.

7. N.S. Bibi, N.K. Singh, R.N. Dsouza, M. Aasim, M.F. Lahore, Synthesis and performance of megaporous immobilized metalion affinity cryogels for recombinant protein capture and purification, J. Chromatogr. A., 1272 (2013) 145-149.

8. Fatoni, A. Numnuam, P. Kanatharana, W. Limbut, P. Thavarungkul, A novel molecularly imprinted chitosanacrylamide, graphene, ferrocene composite cryogel biosensor used to detect microalbumin, Analyst., 139 (2014) 6160-6167.

9. S.P. Tao, C. Wang, Y. Sun, Coating of nanoparticles on cryogel surface and subsequent double-modification for enhanced ion-exchange capacity of protein, J. Chromatog. A., 1359 (2014) 76-83.

10. M. Andaç, G. Baydemir, H. Yavuz, A. Denizli, Molecularly imprinted composite cryogel for albumin depletion from human serum, J. Mol. Recognit., 25 (2012) 555-563.

11. K.R. Hixon, T. Lu, S.A. Sell, A comprehensive review of cryogels and their roles in tissue engineering applications, Acta Biomater., 62 (2017) 29-41.

12. T.M.A. Henderson, K. Ladewig, D.N. Haylock, K.M. McLean, A.J. O'Connor, Cryogels for biomedical applications, J. Mater. Chem. B, 1 (2013) 2682-2695.

13. M. Andac, F.M. Plieva, A. Denizli, I. Y. Galaev, B. Mattiasson, Poly(hydroxyethyl methacrylate)-based macroporous hydrogels with bisulfide cross-linker, Macromol. Chem. Phys. 209 (2008) 577-584.

14. M. Bakhshpour, N. Idil, I. Perçin, A. Denizli, Biomedical Applications of Polymeric Cryogels. Appl. Sci., 9 (2019) 553.

15. W.P. Daley, S.B. Peters, M. Larsen, Extracellular matrix dynamics in development and regenerative medicine, J. Cell Sci., 121 (2008) 255-264.

16. F.J. O'Brien, Biomaterials \& scaffolds for tissue engineering Mater. Today, 14 (2011) 88-95.

17. Tripathi, A.; Kathuria, N.; Kumar, A. Elastic and macroporous agarose-gelatin cryogels with isotropic and anisotropic porosity for tissue engineering, J. Biomed. Mater. Res. A, 90 (2009) 680-694

18. S. Bhat, A. Tripathi, A. Kumar, Supermacroprous chitosanagarose-gelatin cryogels: In vitro characterization and in vivo assessment for cartilage tissue engineering, J. R. Soc. Interface., 8 (2011) 540-554.

19. V.I. Lozinsky, I.Y. Galaev, F.M. Plieva, I.N. Savina, H. Jungvid, B. Mattiasson, Polymeric cryogels as promising materials of biotechnological interest, Trends Biotechnol., 21 (2003) 445451.

20. R. Mishra, A. Kumar, Effect of plasma polymerization on physicochemical properties of biocomposite cryogels causing a differential behavior of human osteoblasts, J. Colloid Interface Sci., 431 (2014) 139-148.

21. S. Bhat, L. Lidgren, A. Kumar, In Vitro Neo-cartilage formation on a three-dimensional composite polymeric cryogel matrix, Macromol. Biosci., 13 (2013) 827-837.

22. S. Gupta, P.R. Bhat, B.P. Jagdale, L. Chaudhari, K.C. Lidgren, A. Kumar, Evaluation of three-dimensional chitosan-agarosegelatin cryogel scaffold for the repair of subchondral cartilage defects: an in vivo study in a rabbit model, Tissue Eng. Part A., 20 (2014) 3101-3111.

23. R. Mishra, S.K. Goel, K.C. Gupta, A. Kumar, Biocomposite cryogels as tissue engineered biomaterials for regeneration of critical-sized cranial bone defects, Tissue Eng. Part A., 20 (2013) 751-62.

24. C.L. Salgado, L. Grenho, M.H. Fernandes, B.J. Colaço, F.J. Monteiro, Biodegradation, biocompatibility, and osteoconduction evaluation of collagen-nanohydroxyapatite cryogels for bone tissue regeneration, J. Biomed. Mater. Res. Part A., 104 (2016) 57-70.

25. S.S. Suner, S. Demirci, B. Yetiskin, R. Fakhrullin, E. Naumenko, O. Okay, R.S. Ayyala, N. Sahiner, Cryogel composites based on hyaluronic acid and halloysite nanotubes as scaffold for tissue engineering, Int. J. Biol. Macromol., 130 (2019) 627635.

26. K.R. Hixon, C.T. Eberlin, T. Lu, S.M. Neal, N.D. Case, S.H. McBride-Gagyi, S.A. Sell, The calcification potential of cryogel scaffolds incorporated with various forms of hydroxyapatite for bone regeneration, Biomed. Mater., 12 (2017) 025005.

27. D.B. Raina, H. Isaksson, A.K. Teotia, L. Lidgren, M. Tägil, A. Kumar, Biocomposite macroporous cryogels as potential carrier scaffolds for bone active agents augmenting bone regeneration, J. Control. Release., 235 (2016) 365-378.

28. I.U. Allan, B.A. Tolhurst, R.V. Shevchenko, M.B. Dainiak, M. Illsley, A. Ivanov, H.; Jungvid, I.Y. Galaev, S.L. James, S.V. Mikhalovsky, S.E. James, An: In vitro evaluation of fibrinogen and gelatin containing cryogels as dermal regeneration scaffolds, Biomater. Sci., 4 (2016) 1007-1014.

29. T. Takei, H. Nakahara, S. Tanaka, H. Nishimata, M. Yoshida, K. Kawakami, Effect of chitosan-gluconic acid conjugate/ poly(vinyl alcohol) cryogels as wound dressing on partialthickness wounds in diabetic rats, J. Mater. Sci. Mater. Med., 24 (2013) 2479-2487.

30. N. A. Temofeew, K. R. Hixon, S.H. McBride-Gagyi, S.A. Sell, The fabrication of cryogel scaffolds incorporated with poloxamer 407 for potential use in the regeneration of the nucleus pulposus. J. Mater. Sci. Mater. Med., 28 (2017) 36.

31. N.X. Wang, H.A. von Recum, Affinity-based drug delivery, Macromol. Biosci., 11 (2011) 321-332.

32. G. P. Carino, E. Mathiowitz, Oral insulin delivery. Adv. Drug. Deliv. Rev., 35 (1999) 249-257.

33. V.P. Torchilin, R. Rammohan, V. Weissig, T.S. Levchenko, Tat peptide on the surface of liposomes affords their efficient intracellular delivery even at low temperature and in the presence of metabolic inhibitors, Proc. Natl. Acad. Sci. U.S.A., 98 (2001) 8786-8791.

34. K.E. Uhrich, S.M. Cannizzaro, R.S. Langer, K.M. Shakesheff, Polymeric systems for controlled drug release, Chem. Rev. 99 (1999) 3181-3198.

35. J. Kopeček, J. Yang, Hydrogels as smart biomaterials, Polym. Intern., 56 (2007) 1078-1098. 
36. K. Cetin, H. Alkan, N. Bereli, A. Denizli, Molecularly imprinted cryogel as a $\mathrm{pH}$-responsive delivery system for doxorubicin J. Macromol. Sci., Part A., 54 (2017) 502-508.

37. M.A. Ward, T.K. Georgiou, Thermoresponsive polymers for biomedical applications, Polymers (Basel). 3 (2011) 1215 1242.

38. W. Zhu, H. Peng, M. Luo, N. Yu, H.; Xiong, R. Wang, Y. Li, Zipper-like magnetic molecularly imprinted microspheres for on/off-switchable recognition and extraction of $17 \beta$-estradiol from food samples, Food Chem., 261 (2018) 87-95.

39. K. Sawahata, M. Hara, H. Yasunaga, Y. Osada, Electrically controlled drug delivery system using polyelectrolyte gels, J. Controlled Release., 14 (1990) 253-262.

40. I.C. Kwon, Y.H. Bae, T. Okano, S.W. Kim, Drug release from electric current sensitive polymers, J. Controlled Release., 17 (1991) 149-156.

41. M. Bakhshpour, H. Yavuz, A. Denizli, Controlled release of mitomycin C from PHEMAH-Cu(II) cryogel membranes, Artif. Cells. Nanomed. Biotechnol., 46 (2018) 946-954

42. D.R. Kryscio, N.A. Peppas, Critical review and perspective of macromolecularly imprinted polymers. Acta Biomater. 8(2) (2012) 461-473.

43. Luchini, D.H. Geho, B. Bishop, D. Tran, C. Xia, R.L. Dufour, C.D. Jones, V.; Espina, A. Patanarut, W. Zhou, M.M. Ross, A Tessitore, E.F. Petricoin, L.A. Liotta, Smart Hydrogel Particles: Biomarker Harvesting, One-Step Affinity Purification, Size Exclusion, and Protection against Degradation, Nano. Lett. 8 (2008) 350-361.

44. J.M. Knipe, F. Chen, N.A. Peppas, Enzymatic biodegradation of hydrogels for protein delivery targeted to the small intestine, Biomacromol., 16 (2015) 962-972.

45. C.E. Brubaker, P.B. Messersmith, Enzymatically degradable mussel-inspired adhesive hydrogel, Biomacromol., 12 (2011) 4326-4334.

46. Mamada, T. Tanaka, D. Kungwachakun, M. Irie, Photo induced phase transition of gels, Macromolecules., 23 (1990) 1517-1519.

47. J. Kost, R. Langer, Responsive polymeric delivery systems, Adv. Drug Deliv. Rev., 64 (2012) 327-341.

48. M.V. Dinu, A.I. Cocarta, E.S. Dragan, Synthesis, characterization and drug release properties of 3Dchitosan/ clinoptilolite biocomposite cryogels, Carbohyd. Poly., 153 (2016) 203-211.

49. E. Tamahkar, M. Bakhshpour, A. Denizli, Molecularly imprinted composite bacterial cellulose nanofibers for antibiotic release, J Biomater Sci Polym Ed Title(s), 6 (2019) 450-461.

50. M. Caka, T. Ceren, D.A. Uygun, M. Uygun, S. Akgöl, A. Denizli, Controlled release of curcumin from poly(HEMA-MAPA) membrane, Artif. Cells Nanomed. Biotechnol., 45 (2017) 426-431.

51. B. Kostova, D. Momekova, P. Petrov, G. Momekov, N. Toncheva-Moncheva, C.B. Tsvetanov, N. Lambov, Poly(ethoxytriethyleneglycol acrylate) cryogels as novel sustained drug release systems for oral application, Polymer 52 (2011) 1217-1222.

52. Gokturk, A. Derazshamshir, F. Yılmaz, A. Denizli, Poly(vinyl alcohol)/polyethyleneimine (PVA/PEI) blended monolithic cryogel columns for the depletion of haemoglobin from human blood, Sep. Sci. Technol, 51 (2016) 1787-1797.

53. C. Yang, Y. Zhang, W.Q. Cao, X.F. Ji J. Wang, Y.N. Yan, T.L. Zhong, Y. Wang, Synthesis of molecularly imprinted cryogels to deplete abundant proteins from bovine serum, Polymers. 10 (2018) 97
54. J.X. Yun, G.R. Jespersen, H. Kirsebom, P.E. Gustavsson, B. Mattiasson, I.Y. Galaev, An improved capillary model for describing the microstructure characteristics, fluid hydrodynamics and breakthrough performance of proteins in cryogel beds, J. Chromatogr. A, 1218 (2011) 5487-5497.

55. R.D. Arrua, C.I.A. Igarzabal, Macroporous monolithic supports for affinity chromatography, J. Sep. Sci., 34 (2011) 1974-1987.

56. S. Sun, Y. Tang, Q. Fu, X. Liu, L. Guo, Y. Zhao, C. Chang, Monolithic cryogels made of agarose-chitosan composite and loaded with agarose beads for purification of immunoglobulin G, Int. J. Biol. Macromol., 50 (2012) 10021007.

57. M. Bakhshpour, N. Bereli, S. Senel, Preparation and characterization of thiophilic cryogels with 2-mercapto ethanol as the ligand for IgG purification. Colloid. Surface. B., 113 (2014) 261-268.

58. M. Bakhshpour, A. Derazshamshir, N. Bereli, A. Elkak, A. Denizli, [PHEMA/PEI]-Cu(II) based immobilized metal affinity chromatography cryogels: Application on the separation of IgG from human plasma, Mater. Sci. Engin. C. 61 (2016) 824-831.

59. Y. Saylan, N. Bereli, L. Uzun, A. Denizli, Monolithic boronate affinity columns for IgG separation, Sep. Sci. Technol., 49 (2014) 1555-1565

60. C. Yang, X.L. Zhou, Y.R. Liu, Y. Zhang, J. Wang, L.L. Tian Y.N. Yan, Extensive imprinting adaptability of polyacrylamide based amphoteric cryogels against protein molecules, Chin. J. Anal. Chem., 44 (2016) 1322-1327.

61. S. Zhao, D. Wang, S. Zhu, X. Liu, H. Zhang, 3D cryogel composites as adsorbent for isolation of protein and small molecules, Talanta., 191 (2019) 229-234.

62. M. Andaç, A. Denizli, Affinity-recognition-based polymeric cryogels for protein depletion studies, RSC Adv., 4 (2014) 31130-31141.

63. M. Andaç, I.Y. Galaev, A. Denizli, Affinity based and molecularly imprinted cryogels: Applications in biomacromolecule purification, J. Chromatogr. B, 1021 (2016) 69-80.

64. M. Andac, I.Y. Galaev, A. Denizli, Molecularly Imprinted Cryogels for Protein Purification: Chapter 22., In Biomaterials from Nature for Advanced Devices and Therapies, Eds: Nuno M. Neves, Rui L. Reis; Wiley, USA ISBN: 978-1-118-47805-9. 2016 403-428.

65. H. Alkan, N. Bereli, Z. Baysal, A. Denizli, Selective removal of the autoantibodies from rheumatoid arthritis patient plasma using protein A carrying affinity cryogels, Biochem. Eng. J., 51 (2010) 153-159.

66. Perçin, G. Baydemir, B. Ergün, A. Denizli, Macroporous PHEMA-based cryogel discs for bilirubin removal, Artif. Cell. Nanomed. B., 41 (2013) 172-177.

67. W. Akande, L. Mikhalovska, S. James, S. Mikhalovsky, Affinity binding macroporous monolithic cryogel as a matrix for extracorporeal apheresis medical devices, Int. J. Biomed. Mater. Res., 3 (2015) 56-63.

68. C. Yang, Y. Zhang, W.Q. Cao, X.F. Ji, J. Wang, Y.N. Yan, T.L. Zhong, Y., Wang, Synthesis of molecularly imprinted cryogels to deplete abundant proteins from bovine serum, Polymer., 10 (2018) 97

69. K. Zhao, T. Chen, B. Lin, W. Cui, B. Kan, N. Yang, X. Zhou, X. Zhang, $K$, J., Wei, Adsorption and recognition of protein molecular imprinted calcium alginate/polyacrylamide hydrogel film with good regeneration performance and high toughness, React. Funct. Polym., 87 (2015) 7-14. 
70. C. Yang, Y.R. Liu, Y. Zhang, J. Wang, L.L. Tian, Y.N. Yan, W.Q. Cao, Y.Y. Wang, Depletion of abundant human serum proteins by per se imprinted cryogels based on sample heterogeneity, Proteomics., 17 (2017) 1600284.

71. C. Yang, X.L. Zhou, Y.R. Liu, J. Wang, L.L. Tian, Y. Zhang, X.Y. $\mathrm{Hu}$, Charged groups synergically enhance protein imprinting in amphoteric polyacrylamide cryogels, J. Appl. Polym. Sci., 113 (2016) 43851.

72. M.E. Çorman, C. Armutcu, S. Özkara, L. Uzun, A. Denizli, Molecularly imprinted cryogel cartridges for the specific filtration and rapid separation of interferon alpha, RSC Adv. 5 (2015) 45015.

73. G. Baydemir, M. Andaç, I. Perçin, A. Derazshamshir, A. Denizli, Molecularly imprinted composite cryogels for hemoglobin depletion from human blood, J. Mol. Recognit., 27 (2014) 528-536.
74. G. Baydemir, E.A. Türkoğlu, M. Andaç, I. Perçin, A. Denizli, Composite cryogels for lysozyme purification, Biotechnol. Appl. Biochem., 62 (2015) 200-207.

75. M. Andaç, G. Baydemir, H. Yavuz, A. Denizli, Molecularly imprinted composite cryogel for albumin depletion from human serum, J. Mol. Recognit., Special Issue (2012) 555563.

76. M. Andaç, I.Y. Galaev, A. Denizli, Molecularly imprinted poly(hydroxyethyl methacrylate) based cryogel for albumin depletion from human serum, Colloid. Surface. B., 109 (2013) 259-265.

77. M. Andac, F. M. Plieva, A. Denizli, I. Yu. Galaev, B. Mattiasson, Poly(hydroxyethyl methacrylate)-based macroporous hydrogels with disulfide cross-linker, Macromol. Chem. Phys., 209 (2008) 577-584. 